\title{
Phase Transformation in Barium Tetraborate
}

\author{
C. R. Robbins and E. M. Levin \\ Institute for Materials Research, National Bureau of Standards, Washington, D.C. 20234
}

(July 17, 1969)

\begin{abstract}
Orthorhombic $\mathrm{BaB}_{8} \mathrm{O}_{13}\left(a=8.550, b=17.352, c=13.211 \AA, D=2.927 \mathrm{~g} / \mathrm{cm}^{3}\right.$ at $\left.25^{\circ} \mathrm{C}\right)$ transforms reversibly at $700{ }^{\circ} \mathrm{C}$ to a high-temperature tetragonal form $\left(a=8.629, c=13.252 \AA, D=2.906 \mathrm{~g} / \mathrm{cm}^{3}\right)$ stable from $700{ }^{\circ} \mathrm{C}$ to the congruent melting point $\left(889^{\circ} \mathrm{C}\right)$ of the compound. The transition is rapid and probably displacive in character. At the transformation point cell constants change discontinuously, doubling of the $b$ axis is lost and cell contents are reduced from $Z=8$ to $Z=4$. Doubling of the $b$ axis reappears with cooling to the transformation temperature and volume strain is relieved by formation of multiple twins or domains. The latent heat of transformation is $2100 \mathrm{~J} / \mathrm{mol}(0.50 \mathrm{kcal} / \mathrm{mol})$ and $d T / d P=-0.0363 \mathrm{~K} / \mathrm{bar}$.
\end{abstract}

Key words: $\mathrm{BaB}_{8} \mathrm{O}_{13}$; heat of transformation; orthorhombic form; polymorphism; tetragonal form.

\section{Introduction}

Barium tetraborate $\left(\mathrm{BaO} .4 \mathrm{~B}_{2} \mathrm{O}_{3}\right)$ was synthesized by Levin and McMurdie $[1]^{1}$ in their study of the binary system $\mathrm{BaO}-\mathrm{B}_{2} \mathrm{O}_{3}$. The compound was found to melt congruently at $889{ }^{\circ} \mathrm{C}$ and was obtained as small crystals, many of which showed multiple twinning. They concluded from optical examination that the material was uniaxial negative, or biaxial negative with small optic axial angle.

Single crystals of $\mathrm{BaB}_{8} \mathrm{O}_{13}$ were prepared from the melt by Krogh-Moe [2] and examined by Weissenberg and oscillation x-ray methods. He observed an orthorhombic unit cell with the following lattice constants:

$$
\begin{aligned}
& a=8.56 \AA \\
& b=17.38 \AA \\
& c=13.20 \AA .
\end{aligned}
$$

His calculated density is $2.91 \mathrm{~g} / \mathrm{cm}^{3}$ and there are eight formula units in the cell. The space group was not determined.

Krogh-Moe observed a weak doubling of the $b$ axis which he indicated by writing $b=2 \times 8.69 \AA$. He reported a pseudo tetragonal symmetry and noted that some of his Weissenberg photographs showed twinning, with the twins having parallel $c$ axes and (010) facing (100). This information suggested to the present authors that $\mathrm{BaB}_{8} \mathrm{O}_{13}$ has one or more hightemperature modifications, stable at atmospheric pressure. The objectives of this investigation were: (1) to examine the behavior of the compound when heated from ambient temperatures to the melting point and (2) to characterize any transformations and polymorphs observed.

\footnotetext{
${ }^{1}$ Figures in brackets indicate the literature references at the end of this paper.
}

\section{Materials and Methods}

Crystalline $\mathrm{BaB}_{8} \mathrm{O}_{13}$ was prepared from high purity $\mathrm{BaCO}_{3}$ and $\mathrm{H}_{3} \mathrm{BO}_{3}$ (purity $99.9 \%$, spectrochemical analysis) by solid state reaction [1]; and by growth from the melt on a high-temperature microscope stage. Seeding of the melt to initiate crystallization was necessary because of supercooling. Small crystals and crystalline powders obtained were studied by differential thermal analysis and by x-ray powder diffractometry from ambient temperatures to $850{ }^{\circ} \mathrm{C}$.

\section{Differential Thermal Analysis}

Differential thermal analyses were made of crystalline powder samples in milligram quantities. Samples were heated in 1 mil platinum foil dishes (1/4 in diam) in a commercial DTA apparatus. Powdered $\mathrm{Al}_{2} \mathrm{O}_{3}$ was the reference standard. The heating rate was $10 \% \mathrm{~min}$ and the sensitivity of the differential temperature scale was $13 \mu \mathrm{V} /$ in. The alpha to beta inversion of pure quartz at $573.5^{\circ} \mathrm{C}$ was used to calibrate the equipment.

An endothermic peak at $700{ }^{\circ} \mathrm{C}$ (estimated uncertainty of $5^{\circ}$ ) was observed for all samples of $\mathrm{BaB}_{8} \mathrm{O}_{13}$ when heated from ambient temperatures to the melting point. The effect was rapidly reversible and indicative of the phase transformation; low $\mathrm{BaB}_{8} \mathrm{O}_{13} 700^{\circ} \mathrm{C}$ high $\mathrm{BaB}_{8} \mathrm{O}_{13}$. The transformation was confirmed by high-temperature x-ray diffractometry as discussed in section 4 .

The heat of transformation was determined by the differential thermal analysis method of Levin and McDaniel [3]. This method is based on the use of weight ratios of sample to a nonreactive internal 
standard of known heat of transformation. Levin and McDaniel obtained the following relationship for an unknown heat of transformation, $\Delta H_{1}$ :

$$
\Delta H_{1}=\Delta H_{2}\left(\frac{M_{1}}{M_{2}}\right)\left(\frac{g_{2}}{g_{1}}\right)\left(\frac{A_{1}}{A_{2}}\right)
$$

where,

$\Delta H_{2}=$ heat of transformation of the internal standard in $\mathrm{kcal} / \mathrm{mol}$

$M_{1} / M_{2}=$ molecular weight ratio of the unknown to the standard

$g_{2} / g_{1}=$ weight ratio of the binary mixture

$A_{1} / A_{2}=$ experimentally determined peak area ratio of the two transformations.

Since this is the equation of a line through the origin with slope $\left(\frac{M_{1}}{M_{2}}\right) \times\left(A_{1} / A_{2}\right) /\left(g_{1} / g_{2}\right)$, a linear relationship should exist between weight ratios and area ratios over the range that the assumptions in the derivation are valid.

Experimentally determined transformation ratios for binary mixtures of $\mathrm{BaB}_{8} \mathrm{O}_{13}$ and quartz $\left(\mathrm{SiO}_{2}\right)$ are given in table 1 . Figure 1 shows good linearity between transformation area ratios and weight ratios, indicating adherence to theory. The slope of the line $(0.250)$ and its standard deviation $(0.0025)$ were determined by the method of least squares for a line passing through the origin.

Applying equation (1) to $\mathrm{BaB}_{8} \mathrm{O}_{13}-\mathrm{SiO}_{2}$ mixtures and using a value of $0.28 \mathrm{kcal} / \mathrm{mol}(1170 \mathrm{~J} / \mathrm{mol})^{2}$ for the heat of transformation of alpha to beta quartz:

$$
\begin{aligned}
\Delta H_{\mathrm{BaB}_{8} \mathrm{O}_{13}=0.28} \times\left(\frac{431.82}{60.085}\right) & \times 0.250 \\
= & 0.50 \mathrm{kcal} / \mathrm{mol}(2100 \mathrm{~J} / \mathrm{mol}) .
\end{aligned}
$$

TABLE 1. Ratio of peak areas between low-high transformations in five binary mixtures of $\mathrm{BaO} \cdot 4 \mathrm{~B}_{2} \mathrm{O}_{3}$ and quartz as a function of weight ratios

\begin{tabular}{c|c}
\hline \hline $\begin{array}{c}\mathrm{BaO} \cdot 4 \mathrm{~B}_{2} \mathrm{O}_{3}: \mathrm{SiO}_{2} \\
\text { (weight ratio) }\end{array}$ & $\begin{array}{c}A_{\mathrm{BaO} \cdot 4 \mathrm{~B}_{2} \mathrm{O}_{3}: A_{\mathrm{SiO}_{2}}} \\
\text { (area ratio) }\end{array}$ \\
\hline & 1.000 \\
$4: 1$ & 9.989 \\
& 1.018 \\
\hline & 0.750 \\
$3: 1$ & .769 \\
& .768 \\
\hline & 0.703 \\
$3: 1$ & .800 \\
& .755 \\
\hline & 0.473 \\
& .451 \\
& .469 \\
\hline & 0.509 \\
& .520 \\
& .520 \\
\hline
\end{tabular}

${ }^{2}$ Private communication, V. B. Parker, Thermochemistry Section, National Bureau of Standards.

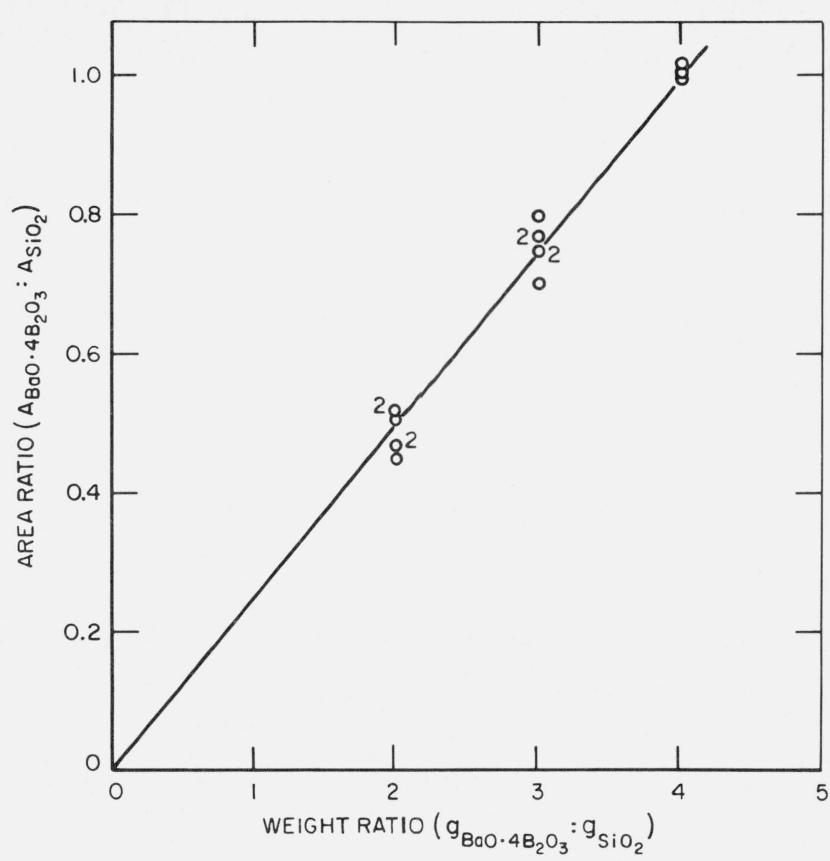

FIGURE 1. Peak area ratios versus weight ratios for mixtures of $\mathrm{BaO} \cdot 4 \mathrm{~B}_{2} \mathrm{O}_{3}$ and $\mathrm{SiO}_{2}$ (quartz). Numbers indicate overlapping data points.

$$
y=0.250 x ; \mathrm{SD}_{\text {(slope) }}=0.0025 ; \mathrm{SD}_{y}=0.028
$$

\section{X-ray Analysis}

X-ray powder diffraction patterns were obtained at temperatures from ambient to $850{ }^{\circ} \mathrm{C}$ using a modified NBS diffractometer furnace [4] and $\mathrm{CuK}_{\alpha_{1}}(\lambda=1.54056 \AA)$ radiation. A standard x-ray diffraction pattern of orthorhombic $\mathrm{BaB}_{8} \mathrm{O}_{13}$ [5] was used to calibrate the equipment at $25^{\circ} \mathrm{C}$. Unit cell dimensions and their standard errors were refined by a least squares calculation using the program of Evans, Appleman, and Handwerker [6]. Estimated uncertainties in temperature measurements in the $\mathrm{x}$-ray study are of the order of $10^{\circ} \mathrm{C}$ on the basis of a transformation temperature of $700^{\circ} \mathrm{C}$ determined by differential thermal analysis.

Unit cell dimensions, cell volumes, and densities of four samples of $\mathrm{BaB}_{8} \mathrm{O}_{13}$ at selected temperatures are listed in table 2. Least-squares calculations for linear fit of the data were done in three ways, using the OMNITAB programming language [7]: (1) by assigning equal weight to each unit cell dimension; (2) by weighting each determination according to the reciprocal of its standard error, as given in table 2; and (3) by weighting each determination according to the reciprocal of the square of its computed standard error, where the computed standard error is calculated using the linear fit equation for the averaged standard errors at each temperature versus temperature. Differences in results obtained using the three weighting methods were insignificant. A least-squares plot of cell constants as a function of temperature (based on method 3) is shown in figure 2. Dashed 
lines show the variation in standard error of individual measurements with temperature. Only the standard error of the orthorhombic $a$ axis changes appreciably with temperature $\left(0.006 \AA\right.$ at $25^{\circ} \mathrm{C}$ to $0.013 \AA$ at $700{ }^{\circ} \mathrm{C}$ ). Figure 3 shows a least-squares plot of density as a function of temperature. Equal weights for each determination were used in the calculation. As may be seen in figure 2, the $a$ and $c$ dimensions of orthorhombic $\mathrm{BaB}_{8} \mathrm{O}_{13} \quad(a=8.550, c=13.211 \AA$ at $\left.25^{\circ} \mathrm{C}\right)$ increase and $b\left(b=17.352 \AA, 25^{\circ} \mathrm{C}\right)$ decreases slightly as the temperature of the compound approaches the transformation temperature, $700^{\circ} \mathrm{C}$. At $700{ }^{\circ} \mathrm{C}, \mathrm{BaB}_{8} \mathrm{O}_{13}$ transforms rapidly and reversibly to a high-temperature tetragonal modification having an $a$ dimension $(a=8.629 \AA)$ intermediate between $a$ and $b / 2$ of the low-temperature orthorhombic form, and with a slightly smaller $c$ axis $(c=13.25 \AA)$. The doubling of the $b$ axis, reported by Krogh-Moe for the low-temperature form, is lost with change in structure at the transformation and cell contents are reduced from eight to four formula units. X-ray powder diffraction data for the orthorhombic form (at $25^{\circ} \mathrm{C}$ ) and for the tetragonal form (at $725^{\circ} \mathrm{C}$ ) are given in table 3. The density increases at the transformation (from $2.891 \mathrm{~g} / \mathrm{cm}^{3}$ to $2.906 \mathrm{~g} / \mathrm{cm}^{3}$ ) and then decreases with temperature increase as seen in figure 3. Application of the Clausius-Clapeyron equation, $d T / d P$ $=T \Delta V \mid \Delta H$ (at one atmosphere), shows an increase in pressure of 1 bar would lower the transition temperature $0.0363 \mathrm{~K}$.

TABLE 2. Unit cell dimensions and their standard errors, cell volume, and density of $\mathrm{BaB}_{8} \mathrm{O}_{13}$ at selected temperatures

\begin{tabular}{l|c|c|c|c|c|c}
\hline \hline Sample & Temp. $\left({ }^{\circ} \mathrm{C}\right)$ & $a(\AA)$ & $b(\AA)$ & $c(\AA)$ & Vol. $(\AA)^{3}$ & $D\left(\mathrm{~g} / \mathrm{cm}^{3}\right)$ \\
\hline
\end{tabular}

Orthorhombic Form

\begin{tabular}{l|l|l|l|l|l|l}
\hline & & & & & & \\
1 & 25 & $8.546 \pm 0.003$ & $17.348 \pm 0.003$ & $13.234 \pm 0.016$ & 1963.5 & 2.921 \\
2 & 25 & $8.550 \pm 0.001$ & $17.353 \pm 0.003$ & $13.194 \pm 0.004$ & 1957.6 & 2.930 \\
3 & 25 & $8.553 \pm 0.003$ & $17.350 \pm 0.003$ & $13.213 \pm 0.005$ & 1960.7 & 2.925 \\
4 & 25 & $8.548 \pm 0.003$ & $17.351 \pm 0.005$ & $13.214 \pm 0.006$ & 1959.8 & 2.927 \\
1 & 200 & $8.551 \pm 0.007$ & $17.348 \pm 0.008$ & $13.260 \pm 0.044$ & 1967.0 & 2.916 \\
2 & 200 & $8.556 \pm 0.003$ & $17.356 \pm 0.003$ & $13.219 \pm 0.006$ & 1962.9 & 2.922 \\
3 & 200 & $8.569 \pm 0.003$ & $17.342 \pm 0.005$ & $13.304 \pm 0.011$ & 1977.1 & 2.901 \\
1 & 300 & $8.567 \pm 0.005$ & $17.363 \pm 0.005$ & $13.243 \pm 0.021$ & 1969.9 & 2.912 \\
1 & 400 & $8.566 \pm 0.005$ & $17.339 \pm 0.007$ & $13.266 \pm 0.023$ & 1978.3 & 2.911 \\
2 & 400 & $8.567 \pm 0.007$ & $17.359 \pm 0.005$ & $13.267 \pm 0.008$ & 1973.8 & 2.907 \\
3 & 400 & $8.572 \pm 0.004$ & $17.348 \pm 0.005$ & $13.301 \pm 0.017$ & 1977.8 & 2.900 \\
4 & 500 & $8.567 \pm 0.004$ & $17.360 \pm 0.004$ & $13.258 \pm 0.020$ & 1970.6 & 2.911 \\
1 & 600 & $8.573 \pm 0.003$ & $17.338 \pm 0.004$ & $13.292 \pm 0.007$ & 1975.8 & 2.903 \\
2 & 600 & $8.601 \pm 0.009$ & $17.337 \pm 0.005$ & $13.320 \pm 0.013$ & 1986.2 & 2.888 \\
3 & 600 & $8.619 \pm 0.007$ & $17.325 \pm 0.005$ & $13.272 \pm 0.009$ & 1981.7 & 2.894 \\
4 & & & & & & \\
2 & 650 & $8.577 \pm 0.008$ & $17.358 \pm 0.006$ & $13.294 \pm 0.019$ & 1979.2 & 2.898 \\
3 & 675 & $8.601 \pm 0.002$ & $17.344 \pm 0.004$ & $13.284 \pm 0.010$ & 1981.7 & 2.894 \\
\end{tabular}

Tetragonal Form

\begin{tabular}{|c|c|c|c|c|c|c|}
\hline 1 & 725 & $8.630 \pm 0.001$ & & $13.268 \pm 0.004$ & 988.2 & 2.902 \\
\hline 2 & 725 & $8.636 \pm 0.001$ & $\cdots$ & $13.279 \pm 0.005$ & 990.3 & 2.896 \\
\hline 3 & 725 & $8.635 \pm 0.001$ & & $13.292 \pm 0.007$ & 991.1 & 2.893 \\
\hline 1 & 750 & $8.630 \pm 0.001$ & & $13.288 \pm 0.006$ & 989.8 & 2.898 \\
\hline 4 & 750 & $8.639 \pm 0.002$ & & $13.252 \pm 0.008$ & 989.0 & 2.900 \\
\hline 3 & 775 & $8.638 \pm 0.003$ & & $13.345 \pm 0.015$ & 995.9 & 2.880 \\
\hline 1 & 800 & $8.641 \pm 0.002$ & & $13.326 \pm 0.006$ & 995.1 & 2.882 \\
\hline 2 & 800 & $8.643 \pm 0.001$ & & $13.337 \pm 0.006$ & 996.3 & 2.878 \\
\hline 1 & 850 & $8.652 \pm 0.002$ & & $13.376 \pm 0.005$ & 1001.2 & 2.865 \\
\hline
\end{tabular}




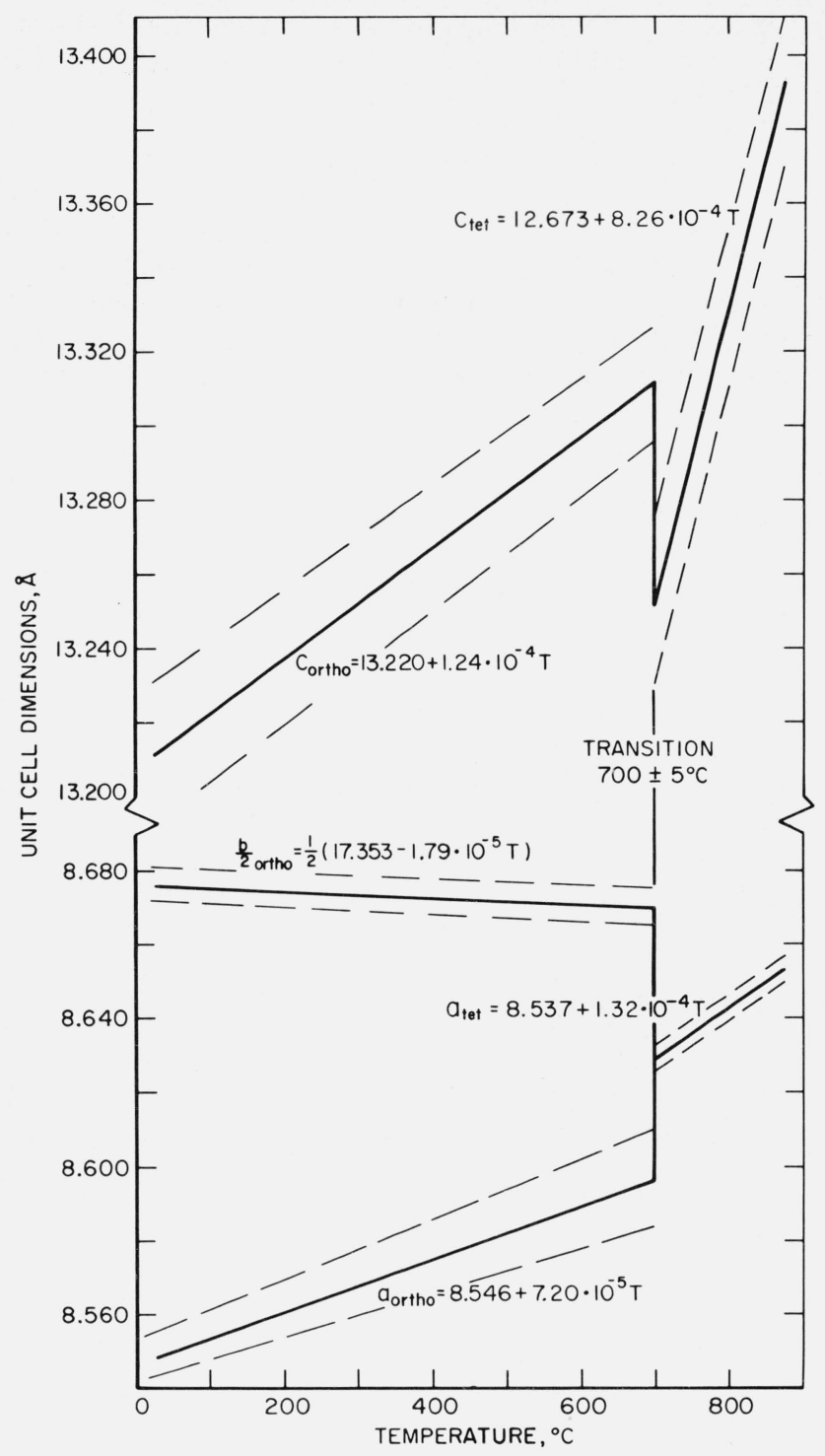

Figure 2. Unit cell dimensions of $\mathrm{BaO} \cdot 4 \mathrm{~B}_{2} \mathrm{O}_{3}$ as a function of temperature.

Selected standard deviations of single measurements are: (Orthorhombic form) (Tetragonal form) $25^{\circ} \mathrm{C} \quad 700{ }^{\circ} \mathrm{C} \quad 700{ }^{\circ} \mathrm{C} \quad 800^{\circ} \mathrm{C}$ $\mathrm{SD}_{a}=0.006 \AA \quad 0.013 \AA \quad \mathrm{SD}_{a}=0.003 \AA \quad 0.004 \AA$ $\mathrm{SD}_{b}=0.010 \AA \quad 0.010 \AA \quad \mathrm{SD}_{c}=0.024 \AA \quad 0.023 \AA$

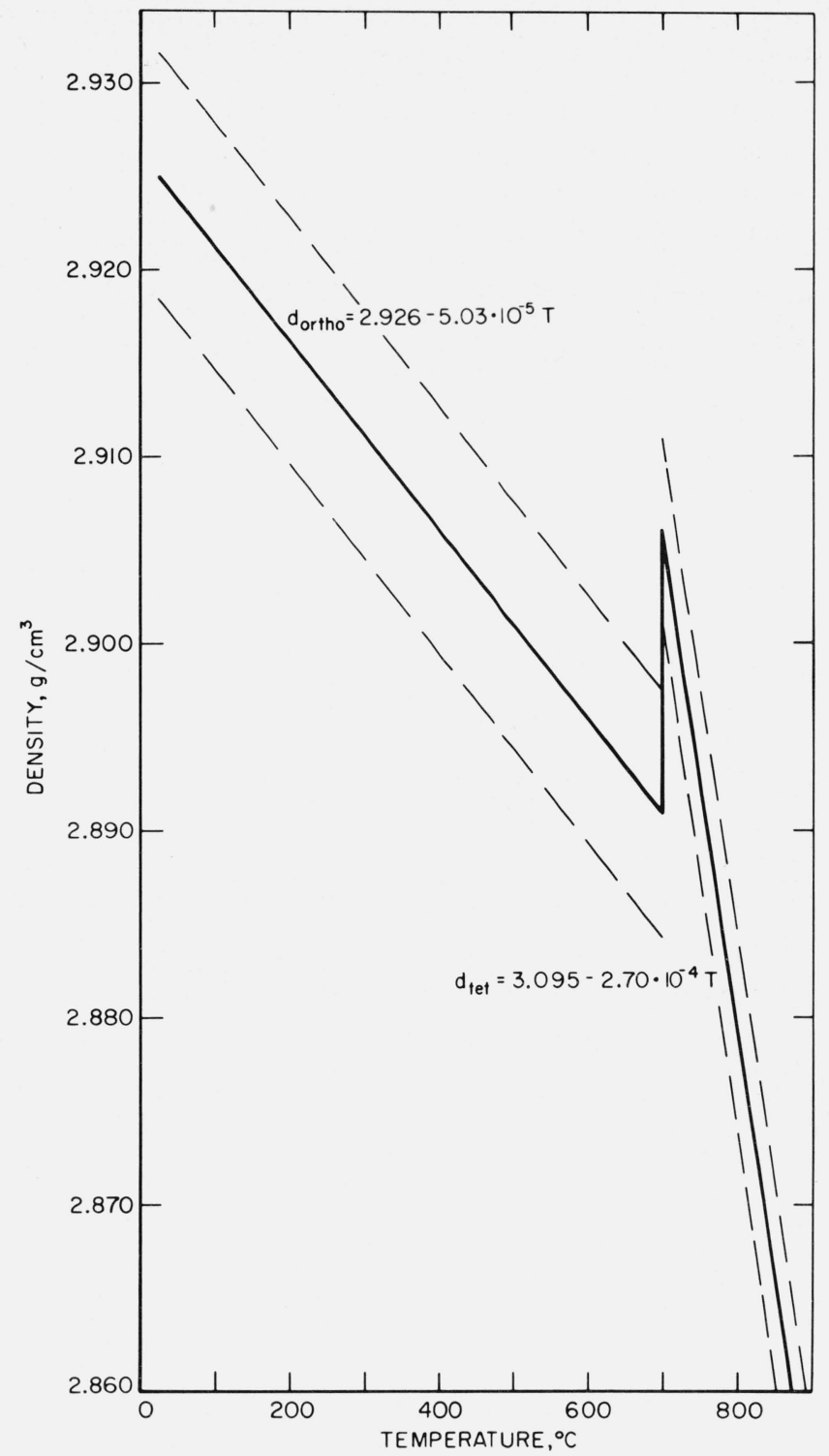

Figure 3. Density of $\mathrm{BaO} \cdot 4 \mathrm{~B}_{2} \mathrm{O}_{3}$ as a function of temperature.

(Orthorhombic form)

(Tetragonal form)

$\mathrm{SD}_{d}=0.0066 \mathrm{~g} / \mathrm{cm}^{3}$ $\mathrm{SD}_{d}=0.0051 \mathrm{~g} / \mathrm{cm}^{3}$ 
TABLE 3. X-ray powder diffraction data for orthorhombic and tetragonal $\mathrm{BaB}_{8} \mathrm{O}_{13}$

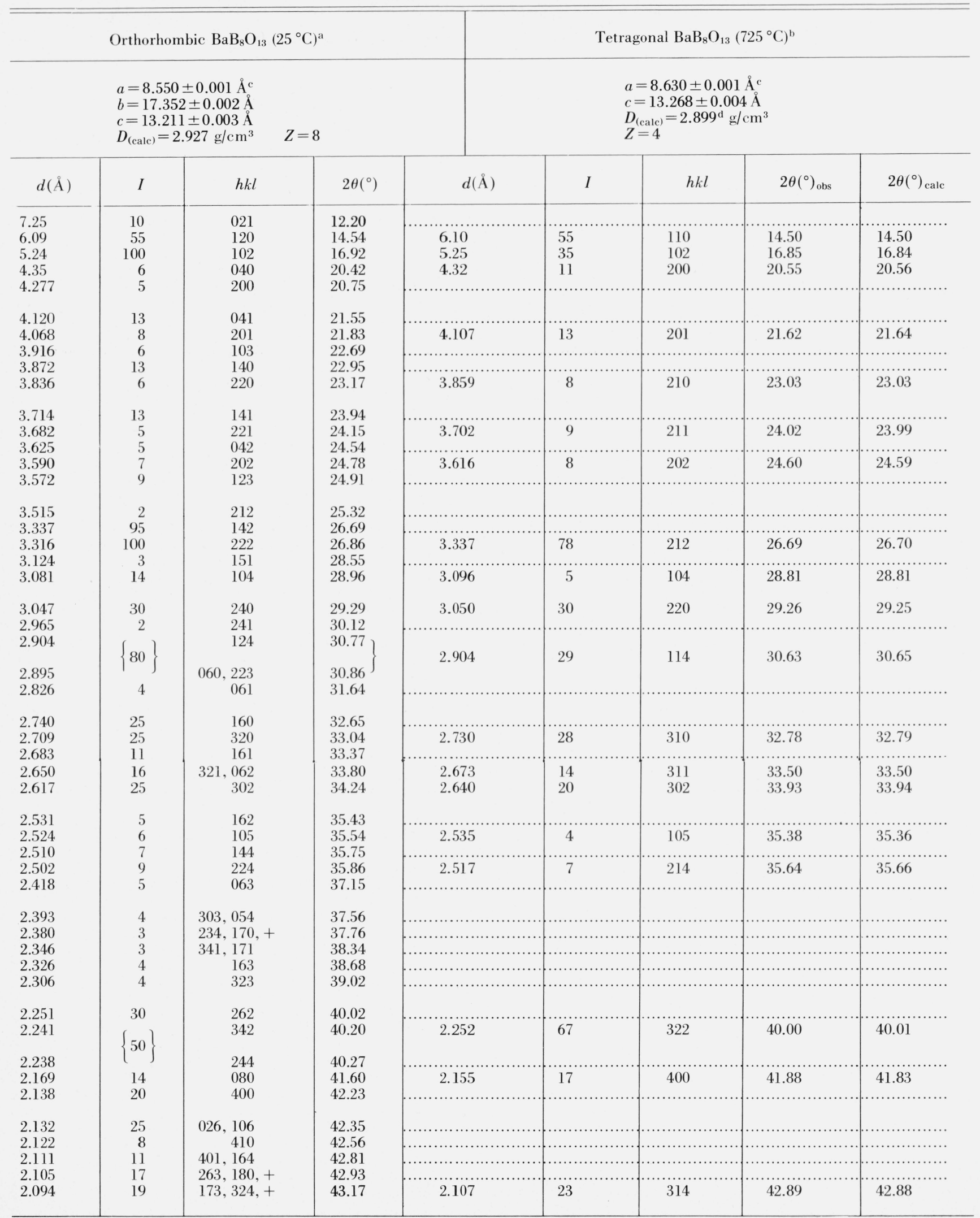


TABLE 3. X-ray powder diffraction data for orthorhombic and tetragonal $\mathrm{BaB}_{8} \mathrm{O}_{13}$ (Continued)

\begin{tabular}{|c|c|c|c|c|c|c|c|c|}
\hline \multicolumn{4}{|c|}{ Orthorhombic $\mathrm{BaB}_{8} \mathrm{O}_{13}\left(25^{\circ} \mathrm{C}\right)^{\mathrm{a}}$} & \multicolumn{5}{|c|}{ Tetragonal $\mathrm{BaB}_{8} \mathrm{O}_{13}\left(725^{\circ} \mathrm{C}\right)^{\mathrm{b}}$} \\
\hline$d(\AA)$ & $I$ & $h k l$ & $2 \theta\left(^{\circ}\right)$ & $d(\AA)$ & $I$ & $h k l$ & $2 \theta\left({ }^{\circ}\right)_{\mathrm{obs}}$ & $2 \theta\left({ }^{\circ}\right)_{\text {calc }}$ \\
\hline 2.076 & 7 & 181,420 & 43.57 & & & & & \\
\hline 2.050 & 6 & 421 & 44.13 & & & & & \\
\hline 2.033 & 3 & 402 & 44.52 & & & & & \\
\hline 2.003 & 10 & 182,136 & 45.24 & & & & & \\
\hline 1.980 & 12 & 422 & 45.79 & 1.996 & 23 & 412 & 45.40 & 45.40 \\
\hline
\end{tabular}

${ }^{a}$ Data from NBS standard pattern $\left(\mathrm{CuK}_{\alpha_{1}}, \lambda=1.54056 \AA\right.$, W standard, $\left.a=3.16516 \AA\right)$. [5]

${ }^{\text {b }}$ From sample 1, table 2 .

${ }^{c}$ Unit cell constants and their standard errors are based on least-squares refinement of the variance-covariance matrix derived from the unweighted $\Delta \theta$ residuals.

${ }^{\mathrm{d}}$ Calculated with equation given in figure 3.

\section{Summary and Conclusions}

Orthorhombic $\mathrm{BaB}_{8} \mathrm{O}_{13}$ transforms reversibly at $700 \pm 5{ }^{\circ} \mathrm{C}$ (and one atmosphere) to a high-temperature tetragonal modification, stable from $700{ }^{\circ} \mathrm{C}$ to the congruent melting point $\left(889^{\circ} \mathrm{C}\right)$ of the compound. The transformation is rapid and probably displacive, with changes in second coordination bonds. If the transformation is displacive, it provides an example of a transformation in which the high-temperature form has a slightly smaller specific volume than the low-temperature form as compared with Buerger's listed criteria for displacive polymorphs [8] in which the reverse is true. At the transformation point all cell constants change discontinuously, the original $b$ axis is halved and the cell contents are reduced from eight to four formula units. The doubling reappears when the high-temperature form is cooled to the transformation temperature, and the resulting volume strain is relieved by formation of multiple twins or domains. The latent heat of transformation is $2100 \mathrm{~J} / \mathrm{mol}(0.50$ $\mathrm{kcal} / \mathrm{mol})$, as compared with $1170 \mathrm{~J} / \mathrm{mol}(0.28 \mathrm{kcal} / \mathrm{mol})$ for the alpha to beta quartz transformation, and $d T / d P=-0.0363 \mathrm{~K} / \mathrm{bar}$.

\section{References}

[1] Levin, E. M., and McMurdie, H. F., The system $\mathrm{BaO}-\mathrm{B}_{2} \mathrm{O}_{3}$, J. Res. NBS 42, No. 2, 131-138 (1949) RP 1956.

[2] Krogh-Moe, J., A note on the structure of barium tetraborate, Acta Chem. Scand. 14 [5], 1229-1230 (1960).

[3] Levin, E. M., and McDaniel, C. L., Heats of transformation in bismuth oxide by differential thermal analysis, J. Res. NBS 69A (Phys. and Chem.), No. 3, 237-243 (1965).

[4] Levin, E. M., and Mauer, F. A., Improved sample holder for x-ray diffractometer furnace, J. Am. Ceram. Soc. 46 [1], 59-60 (1963).

[5] Swanson, H. E., McMurdie, H. F., Morris, M., and Evans, E., Standard x-ray diffraction powder patterns, NBS Monograph 25, Sec. 7 (1969).

[6] Evans, H. T., Jr., Appleman, D. E., and Handwerker, D. S., The least-squares refinement of crystal unit cells with powder diffraction data by an automatic computer indexing method, (Abs.) Am. Crystal Assoc. Annual Meeting, Cambridge, Mass., Program 42-43 (1963).

[7] Hilsenrath, J., Ziegler, G. G., Messina, C. G., Walsh, P. J., and Herbold, R. J., OMNITAB, A computer program for statistical and numerical analysis, NBS Handbook 101 (1966).

[8] Buerger, M. J., Crystallographic aspects of phase transformations, in Phase Transformations in Solids, R. Smoluchowski, J. E. Mayer, and W. A. Weyl, editors, (John Wiley and Sons, New York, 183-211 (1951)).

(Paper73A6-575) 